\title{
On the morphology of the central nervous system in larval stages of Carcinus maenas L. (Decapoda, Brachyura)
}

\author{
S. Harzsch \& R. R. Dawirs* \\ Department of Neuroanatomy, Faculty of Biology, University of Bielefeld; Postbox \\ $100131, D-W-4800$ Bielefeld, Federal Republic of Germany
}

\begin{abstract}
We investigated the morphology of the central nervous system throughout the larval development of Carcinus maenas. For that purpose single larvae were reared in the laboratory from hatching through metamorphosis. Complete series of whole mount semithin sections were obtained from individuals of all successive larval stages and analysed with a light microscope. Morphological feature and spatial arrangement of discernable neural cell clusters, fibre tracts and neuropile are described and compared with the adult pattern. We found that most of the morphological features characterizing the adult nervous system are already present in the zoea-1. Nevertheless, there are marked differences with respect to the arrangement of nerve cell bodies, organization of cerebral neuropile, and disposition of ganglia in the ventral nerve cord. It appears that complexity of the central nervous neuropile is selectively altered during postmetamorphotic development, probably reflecting adaptive changes of sensory-motor integration in response to behavioural maturation. In contrast, during larval development there was little change in the overall structural organization of the central nervous system despite some considerable growth. However, the transition from zoea-4 to megalopa brings about multiple fundamental changes in larval morphology and behavioural pattern. Since central nervous integration should properly adapt to the altered behavioural repertoire of the megalopa, it seems necessary to ask in which respect synaptic rearrangement might characterize development of the central nervous system.
\end{abstract}

\section{INTRODUCTION}

The central nervous system (CNS) of crustaceans has been the subject of extensive investigations by neuroanatomists since the end of the 19th century. Studies by these early workers still basically represent our present knowledge of the crustacean nervous system (Retzius, 1890; Hanström, 1947; Helm, 1928). With regard to the CNS of Carcinus maenas, Bethe's famous "Carcinus Experiment" certainly is of standing importance (Bethe, 1897). Since the exhaustive review of Bullock \& Horridge (1965), in recent years additional aspects of brain morphology have been dealt with in decapod crustaceans (Tsvileneva \& Titova, 1985; Nässel \& Elofsson, 1987; Blaustein et al., 1988), in particular applying immunohistochemical techniques (Sandeman et al., 1988, 1990; Johansson, 1991). A considerable amount of information is available about the ultrastructural

- Address correspondence to Dr. Ralph R. Dawirs at the above address 
organization of central ganglia including the neuropile, nerve cell bodies and glia (Abbott, 1971; Sandeman \& Luff, 1973). Meanwhile, the stomatogastric nervous system of crustaceans is used as a valid model for the study of various neurophysiological aspects (Selverston \& Moulins, 1987; Cournil et al., 1990; Turrigiano \& Selverston, 1991). Anatomy of the thoracic ganglia has been dealt with mainly with respect to the location and physiological properties of motor neurons (Silvey, 1981; Bévengut et al., 1983; Chrachri \& Clarac, 1989). Finally, the abdominal ganglia have been thoroughly investigated (Krasne \& Stirling, 1972; Fedesova, 1978; Tsvileneva, 1978) and locations of motor system elements and projection of sensory afferents are well documented (Leise et al., 1986, 1987).

Despite this extensive range of literature on the adult CNS, a detailed description of the larval nervous system is as yet not available. Neurogenesis during larval development and particularly in the course of metamorphosis, which is commonly referred to as "neurometamorphosis" (Harris, 1990), is a topic that has not been addressed in crustaceans (Laverack, 1988a, b). On the other hand, recent reviews outline the significance of hormonal actions (Levine \& Weeks, 1990), persistent neural elements (Breidbach, 1990), programmed cell death, structural remodelling (Truman, 1990) and synaptic refinement (Lnenicka \& Murphey, 1989) during neurometamorphosis of insects. However, metamorphosis is quite different in holometabolous insects and decapod crustaceans. Since there is nothing resembling the insect resting stage, the nervous system of decapod crustacean larvae remains functional throughout metamorphosis. Therefore it is likely that insects and crustaceans reveal considerably different strategies in structural adaptation of the CNS during transition from larvae to the adults.

The present paper gives a detailed description of light-microscopical structures of the larval central nervous system of $C$. maenas. Morphological characteristics are discussed, together with differences from the adult feature as described in previous reports.

\section{MATERIALS AND METHODS}

\section{Larvae}

Ovigerous females of Carcinus maenas were collected from the western rocky intertidal zone of the Island of Helgoland (North Sea, German Bight). In the laboratory, animals were kept in a flow-through system, in natural seawater. Newly hatched larvae were immediately separated from the adults and individually reared in glass vials at a constant $18^{\circ} \mathrm{C}$. They were fed on a diet of brine shrimp nauplii, Artemia spp., and the rotifer, Brachionus plicatilis (Dawirs, 1982). This method allows an exact determination of the larval stage and age of the animals.

\section{Serial sections}

Larvae were fixed in glutaraldehyde $(5 \%, 1 \mathrm{~h})$, postfixed in 0s04 $(2 \%, 1 \mathrm{~h})$ and embedded in Epon (Serva). Section series of the larval nervous system were obtained in horizontal, frontal and sagittal planes (Ultracut, Reichert-Jung). Sections $(1 \mu \mathrm{m})$ were stained in 1,4-phenylenediamine dissolved in a 1:1 mixture of methanol and 2-propanol (Holländer \& Vaaland, 1968), mounted in DePeX (Serva) and coverslipped. For light 
microscopy (Reichert-Jung, Polyvar), 18 larvae were processed in this way, including the stages zoea-1 to zoea-4 and megalopa. A total of 5572 slices were analysed.

Nomenclature and abbreviations are based on Helm (1928) as reviewed by Bullock \& Horridge (1965) and confirmed by Tsvileneva \& Titova (1985). Unless otherwise defined the photomicrographs of frontal and sagittal sections have the following directions: right (rostral), left (caudal), above (dorsal), below (ventral). In horizontal sections, above and below means left and right.

\section{RESULTS}

\section{Megalopa: optic lobes and brain}

The neuropile of the cerebral ganglion and optic lobes are almost entirely surrounded by a cortex of cell somata of which the typical diameter is $8-10 \mu \mathrm{m}$. In some regions the layer of cell bodies expands to thick clusters, appearing as rounded lobes. The most anterior cluster is formed by the anterior medial cells (AMC). This group of cells is located medially between the trunks of the protocerebral tracts (PCT) reaching the ventral cell cortex (Figs 1a, c, d, 5). Dorsally there is no distinct boundary which separates the AMC from the paired lobes of the anterior dorsal cells (ADC) (Figs 1a, e-i). Neurites of the cells in these conspicuous, spherical clusters enter the medial protocerebrum close to the optic neuropiles (Fig. 1a). Three giant neurons (GN) 20-25 $\mu \mathrm{m}$ in diameter, have frequently been found to be situated at the medial rim of these lobes (Figs $1 \mathrm{~h}, \mathrm{i}$ ). Caudally to the $A D C$, the cell cortex expands to form the cluster of the posterior dorsal cells (PDC) (Figs $1 \mathrm{~h}-\mathrm{k}$ ). From here a thick cell layer reaches down ventrally behind the neuropile of the olfactory lobes (OL). This layer joins the posterior ventral cells (PVC), a lobe which is situated ventrally between the olfactory lobe and the tritocerebrum (Figs $1 j-n, 5$ ).

In the eyestalks, the optic neuropiles next to the retina $(R)$ are the lamina ganglionaris (LG), external (EM) and internal medulla (IM) (Figs 1b, 5). The lamina ganglionaris and, to a lesser extent, the internal medulla show a regular neuropilar organization, probably due to the geometrical arrangement of retinal sensory cells, the axons of which project to the lamina ganglionaris. Fibres connecting the lamina ganglionaris to the external medulla form a chiasma (Fig. 1b). The terminal medulla (TM) is the biggest eyestalk neuropile mass most distal to the retina (Figs 1b, 5). The optic lobes are linked to the brain by the protocerebral tracts (PCT) (Figs 1c, 5). Part of the protocerebral tract is the olfactory-globular tract (OGT), connecting the olfactory lobe (OL) to the terminal medulla (TM) (Figs 1a, d-k, 5).

Sensory information from the optic lobes enters the medial protocerebrum via the protocerebral tract $(\mathrm{PCT})$. Fibres of this tract, entering the dorsal part of the brain underneath the lobe of the anterior dorsal cells (ADC), spread into the dorsal optic neuropile (DONP) (Fig. 1c). More ventrally these glomeruli broaden to form the lateral optic neuropiles (LONP). Medially the LONPs fuse to a very dense neuropile, called the medial optic neuropile (MONP) (Figs 1d-f, 5). The central body (CB) could be identified as a fine spindle-shaped and transversally extending neuropile which is embedded within the MONP (Figs 1f, 5). The central body $(\mathrm{CB})$ is accompanied by small dorsal and ventral commissures and a larger one situated caudally. Some fibres of this latter tract enter the olfactory-globular tracts (OGT), the branches of which meet here and partly cross (Figs 1g, 5). The olfactory lobes (OL) (Figs 1h-n, 5), which form a dense, homogene- 

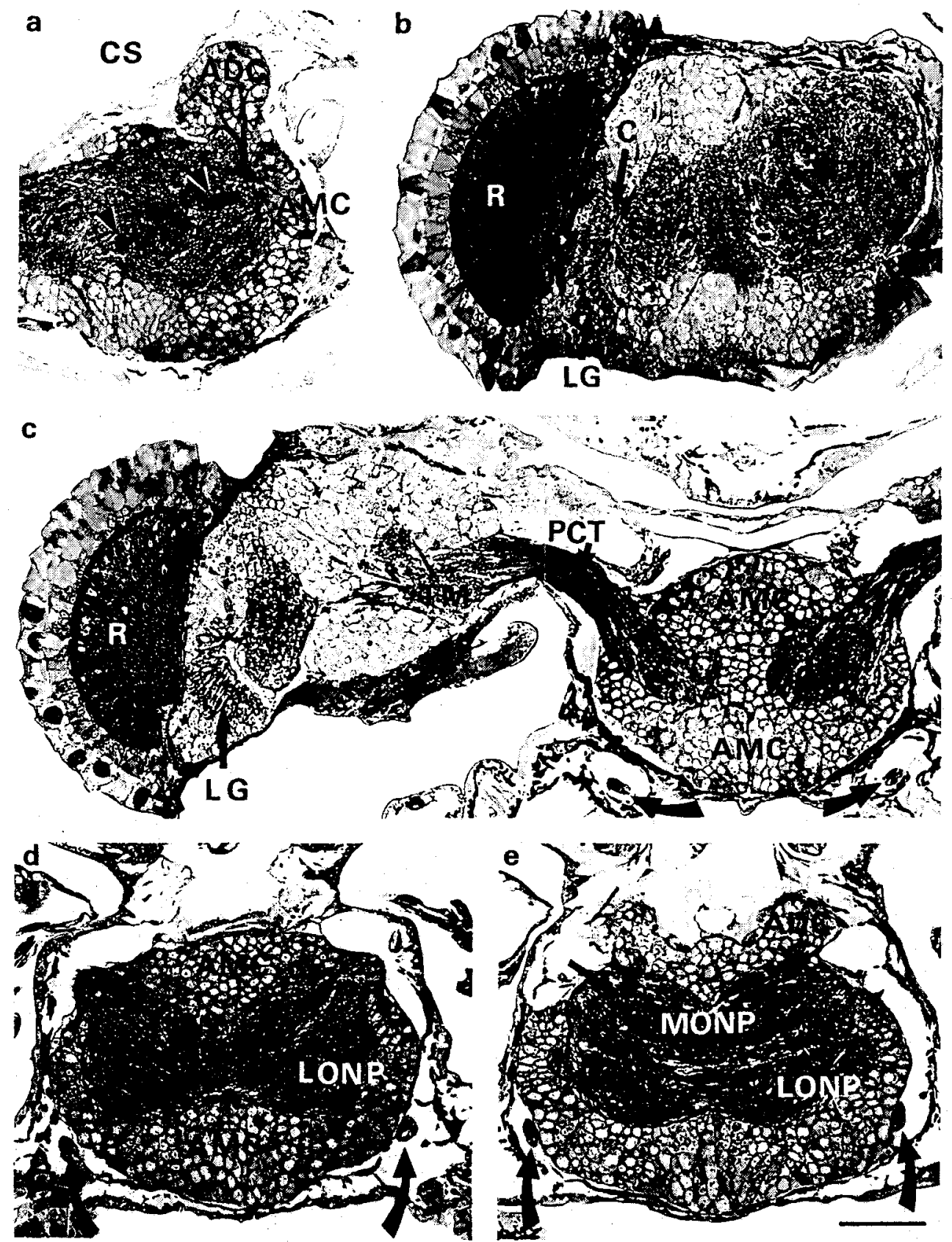
ously structured neuropile, are supplied with sensory input by the antennulary nerve (ALN), ascending from the massive antennules. The antennulary nerve (ALN) enters the brain ventrally beneath the olfactory lobes (OL) (Figs $1 \mathrm{c}-\mathrm{g}, 5$ ).

The olfactory-globular tracts (OGT) are conspicuous bundles of fibres, leaving the olfactory lobes (OL) in a medial direction (Figs $1 \mathrm{j}, \mathrm{k}, 5$ ). As they approach the core of the brain, they change direction and meet anteriorly right at the medial line above the central body (CB). Here some of the fibres cross over to the other side (Figs 1f, $g, 5$ ). Further anteriorly the olfactory globular tracts (OGT) bend upwards and make their way to the lateral protocebrum via the protocerebral tracts (PCT) (Figs 1c-e, 5). Neurites descending from the anterior dorsal cells $(\mathrm{ADC})$ can be found to enter the olfactory globular tract (OGT) on their way into the dorsal part of the brain (Fig. 1e).

A horseshoe-shaped tritocerebral commissure (TC) joins the two halves of the tritocerebral neuropile (TCNP) which is caudally attached to the deutocerebrum (Figs $1 j-n, 5)$. There are two nerves entering the TCNP, the first of which is the antennary nerve (ATN), making its way through the cell cortex in an upward direction (Figs 1m, 5). The second is the tegumentary nerve (TN), situated slightly more caudally to the former, approaching the neuropile from a dorsal direction (Figs 1n, 5). No clear demarcation could be found between the tritocerebral neuropile (TCNP) and the medial part of the deutocerebrum (Fig. 5).

Thick fibre tracts join the tritocerebral neuropile (TCNP) to the neuropile of the commissural ganglions (CG) which are still part of the tritocerebrum. These fibre tracts, called circumesophageal connectives (CEC), make their way caudally through the commissural ganglion (CG) and finally enter the subesophageal ganglion (Figs 1o-q, 5). The two hemiganglia of the commissural ganglion situated laterally to the esophagus ( $E$ ) are connected by the postesophageal commissure (PEC) (Figs 1q, 5).

Part of the adult stomatogastric nervous system are the paired superior and inferior esophageal nerves which arise from the commissural ganglia (CG) and meet on the midline at the esophageal ganglion (EG). These nerves could not be traced with sufficient certainty in the present study, but the esophageal ganglion (EG) was found to be squeezed between the tritocerebral neuropiles (TCNP) on the anterior side of the esophagus (Figs 1l, 5). This small ganglion sends off the stomatogastric nerve (SN) running dorsally to the stomatogastric ganglion (SG) which is situated on the outer wall of the cardiac stomach (CS) (Figs 1h,i).

Fig. 1. Carcinus maenas L. Megalopa, brain; a: parasagittal section of the protocerebrum; $b-q$ : rostro-caudal frontal section series (cf. Fig. 5); $\mathrm{ADC}=$ anterior dorsal cells; $\mathrm{AMC}=$ anterior medial cells; $\mathrm{ATN}=$ antennary nerve; $\mathrm{C}=$ chiasma; $\mathrm{CB}=$ central body; $\mathrm{CEC}=$ circumesophageal connective; $\mathrm{CG}=$ commissural ganglion; $\mathrm{CS}=$ cardiac stomach; $\mathrm{DONP}=$ dorsal optic neuropile; $\mathrm{E}$ = esophagus; $\mathrm{EG}=$ esophageal ganglion; $\mathrm{EM}=$ external medulla; $\mathrm{GN}=$ giant neuron; $\mathrm{IM}=$ internal medulla; $\mathrm{L}=$ labrum; $\mathrm{LG}=$ lamina ganglionaris; $\mathrm{LONP}=$ lateral optic neuropile; $\mathrm{MONP}=$ medial optic neuropile; $\mathrm{OL}=$ olfactory lobe; $\mathrm{PDC}=$ posterior dorsal cells; $\mathrm{PCT}=$ protocerebral tract; $\mathrm{PEC}=$ postesophageal commissure; $\mathrm{PVC}=$ posterior ventral cells; $\mathrm{R}=$ retina; $\mathrm{SG}=$ stomatogastric ganglion; $\mathrm{SN}=$ stomatogastric nerve; $\mathrm{TC}=$ tritocerebral commissure; $\mathrm{TCNP}=$ tritocerebral neuropiles; $\mathrm{TM}=$ terminal medulla; $\mathrm{TN}=$ tegumentary nerve; curved arrows: antennulary nerve; arrowheads: olfactory globular tract; unlettered straight arrows: (e) fibre connections of the anterior dorsal cells (ADC) with the olfactory globular tract; $(\mathrm{g})$ fibre connections of the olfactory globular tract with the commissure caudal from the central body (CB); Scale bars: $50 \mu \mathrm{m}$ 

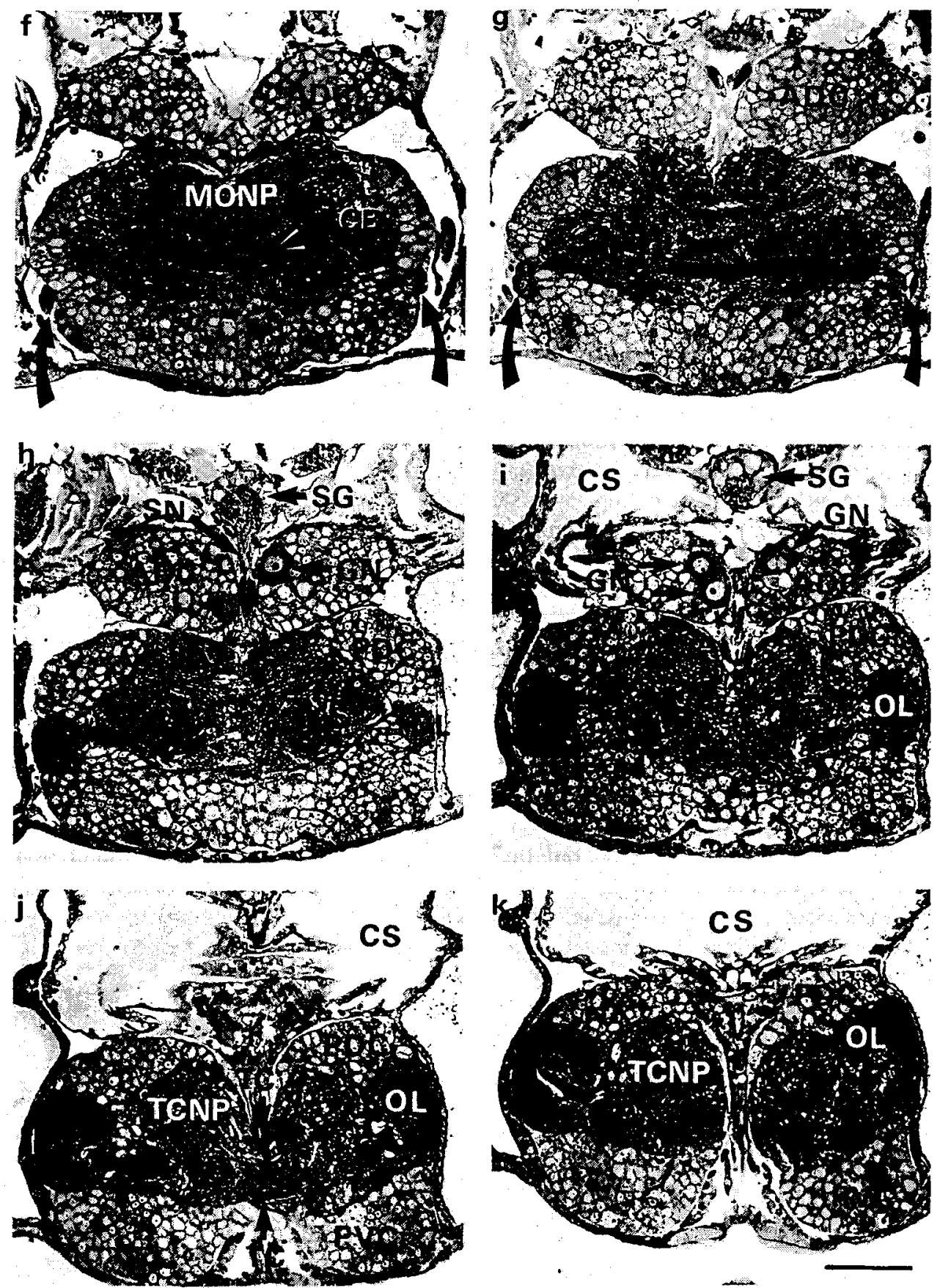

Fig. 1f-k 

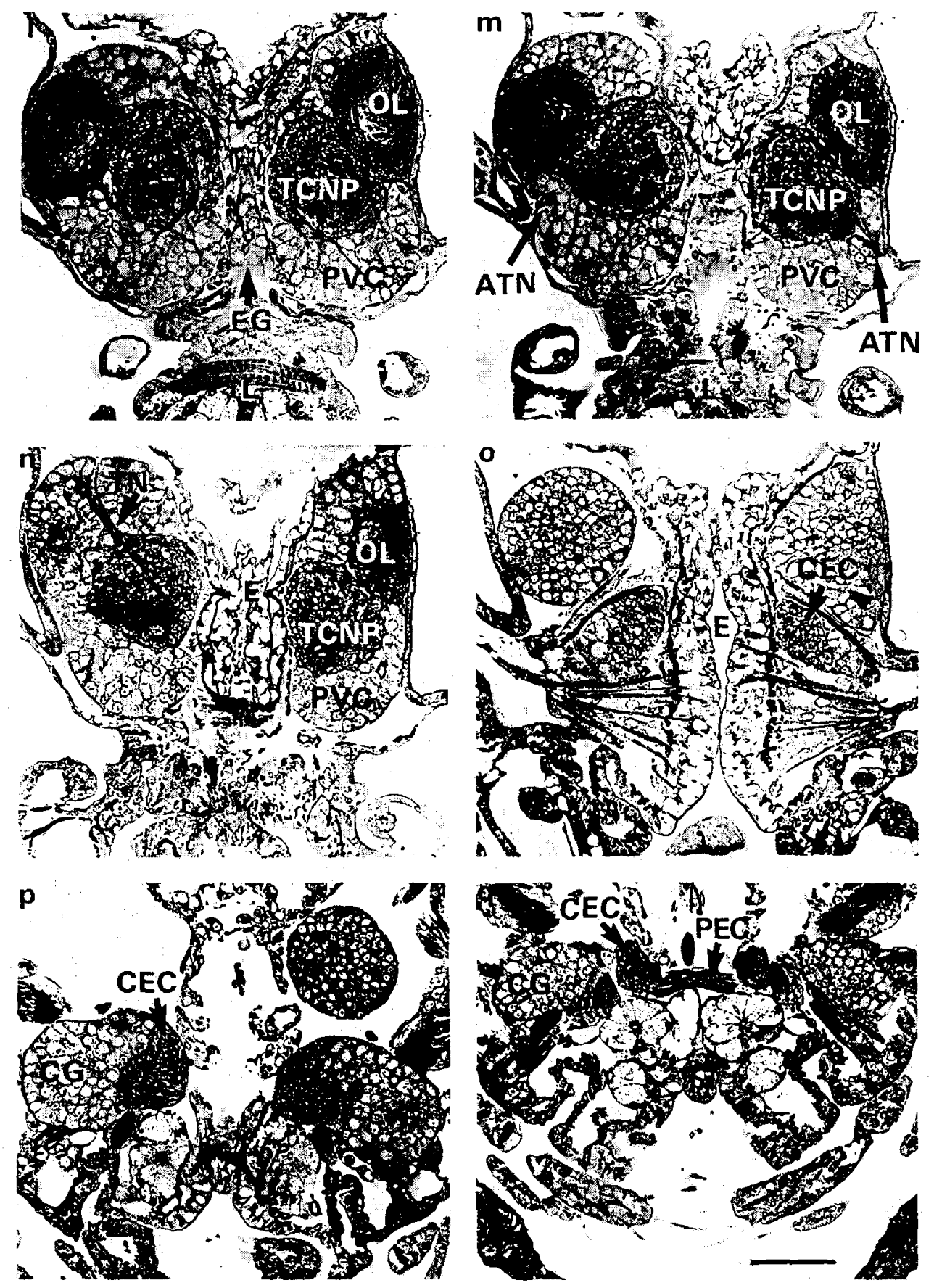


\section{Megalopa: ventral nerve cord}

The ventral nerve cord of Carcinus maenas larvae is of the ladder-like type, with two segmental hemiganglia, joined transversally by commissures and longitudinally by connectives. The subesophageal ganglion (SEG) is situated immediately behind the esophagus and is joined to the tritocerebral parts of the brain by the short and thick circumesophageal connectives (CEC) (Figs 3a,c, 5). It consists of six fused neuromeres, corresponding to the segmental appendages which are the mandibles, maxillules, maxillae, and maxillipeds I to III. Again the subesophageal ganglion (SEG) shows a central neuropile with a thick cortex of cell somata, most of which are situated ventrally (Figs 2a-d). Despite the high degree of fusion, the ladder-like structure of the subesophageal ganglion (SEG) is still discernable. Segmental nerves, originating in the central neuropile, penetrate through the cell layer and leave the ganglion laterally. Furthermore, the segmental pattern is revealed by the arrangement of commissures between the two hemiganglia which can be followed by studying a section series of frontal planes (Figs $2 \mathrm{a}-\mathrm{d}$ ). There is a broad band of longitudinally running fibres in the core of the subesophageal ganglion (SEG). In a horizontal plane, at least three tracts are visible, running through the length of the ganglion on each side (Fig. 3c).

The five thoracic ganglia reveal a lower degree of fusion than the neuromeres of the subesophageal ganglion (SEG) to which they are caudally attached. Five neuropile "glomerula" can be distinguished, which are joined longitudinally by connectives (Figs $3 c, 5)$. On each side of the nerve cord there are two connective tracts, one of which is located in the dorsal part, the other in the ventral part of the neuropile (Fig. 3b). Transversally the neuropiles of the hemiganglia are not entirely fused but are joined to each other by broad commissural tracts. In each segment there is a ventral and a dorsal commissure (Fig. 2d). Again, the segmental pattern can be studied by following the arrangement of commissures and nerve roots, leaving the ganglia laterally. Part of the neuropile is separated by medially situated cell columns (MCC), descending from the dorsal cell cluster and merging with the ventrally situated cells (Figs 2e, 5). The cell cortex in this ventral part of the thoracic ganglia is thicker than in other parts. The conspicuous sternal artery (SA) penetrates the ventral nerve cord between the 3rd and 4th thoracic ganglion, making its way downwards through the corresponding cell column. Ventrally the sternal artery (SA) separates into an anterior and a posterior branch (Figs $3 c, 4 a, 5$ ). The first of the six abdominal ganglia (AG) is attached to the fifth thoracic ganglion. It is a small ganglion which can only be distinguished by a small medially situated artery which arises from the posterior branch of the sternal artery (SA) and ascends between the fifth thoracic ganglion (TG) and the first abdominal ganglion (AG) (Fig. 4a).

Abdominal ganglia 2 to 6 are not fused longitudinally and are clearly discernable (Figs $3 a, 4 b$ ). Segmental nerves leave the ganglia ventrally, running caudally into the corresponding segment of the abdomen (Fig. 4b). Abdominal ganglia (AG) 2 to 5 are bigger than the other two, probably reflecting the fact that segments 2 to 5 bear pleopods as locomotive appendages. The cord of the abdominal ganglia (AG) is laterally displaced, the hindgut running parallel with the ganglia (Fig. 4c).

A schematic model of the whole central nervous system of the megalopa is shown in Figure 5. This model has been reconstructed from complete horizontal, frontal and sagittal section series, and represents a mid dorso-ventral horizontal plane. 

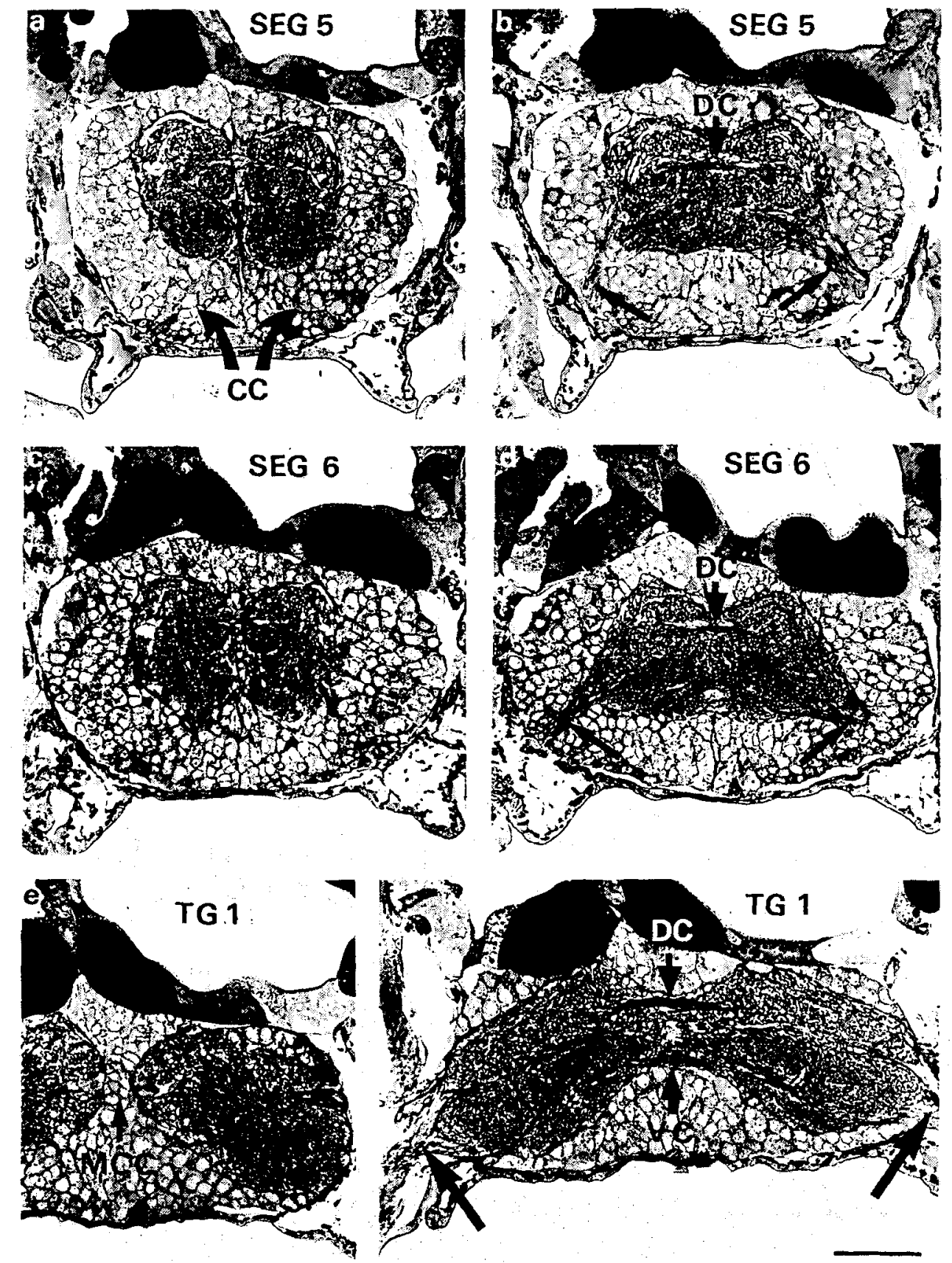

Fig. 2. Carcinus maenas L. Megalopa, ventral nerve cord, rostro-caudal frontal section series from neuromere 5 of the subesophageal ganglion (SEG) to the first thoracic ganglion (TG 1); for position of single sections cf. Fig. $5 ; \mathrm{CC}=$ cell cortex $_{1} \mathrm{rCNP}=$ right central neuropile; $1 \mathrm{CNP}=$ left central neuropile; $\mathrm{DC}=$ dorsal commissure $\mathrm{MCC}=$ medial cell column; $\mathrm{VC}=$ ventral commissure; unlettered arrows: segmental nerve roots; Scale bar: $50 \mu \mathrm{m}$ 

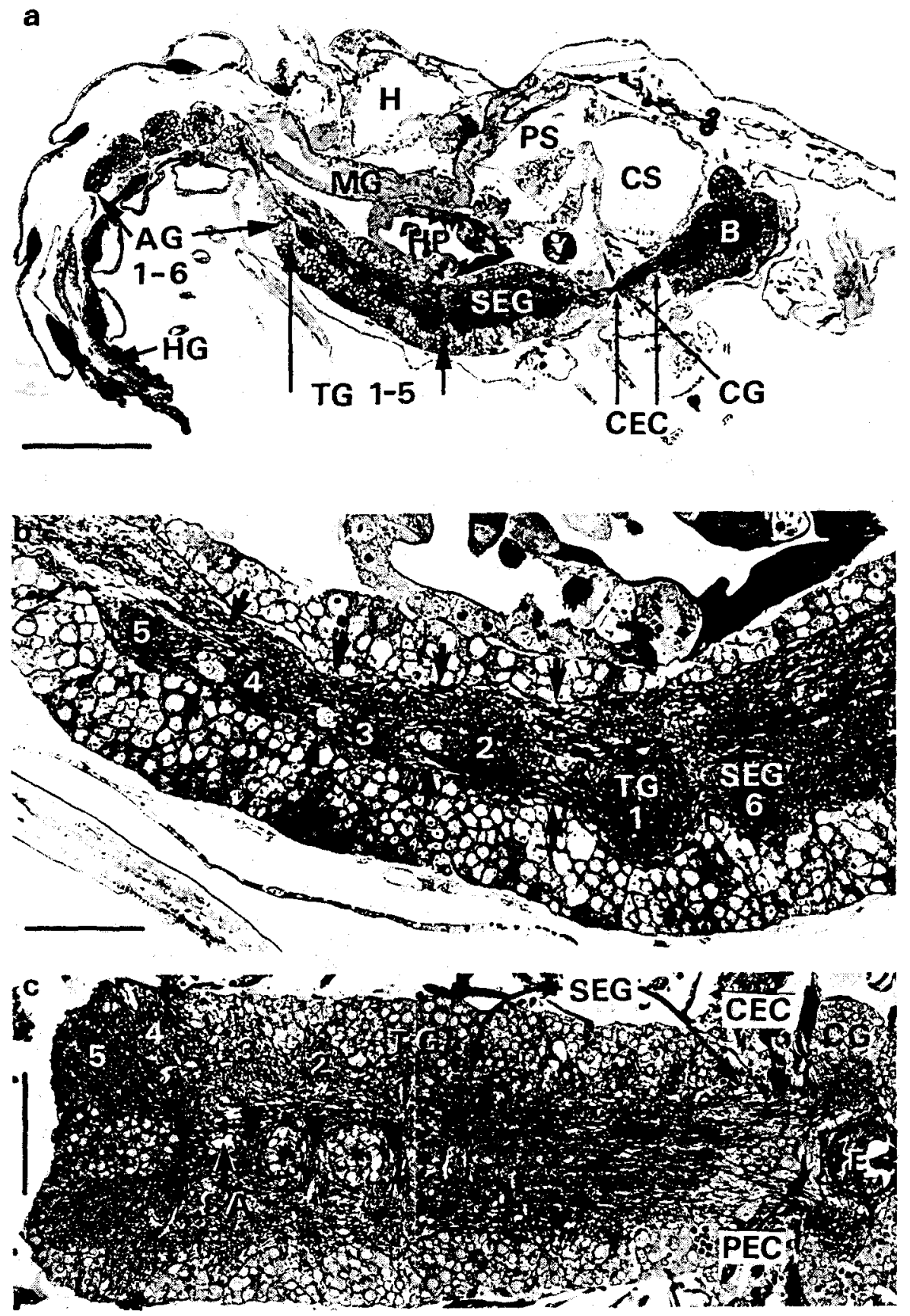


\section{Central nervous system of the zoea}

It appears that all main features of the CNS in the megalopa are already present in the zoea-1. The arrangement of cell clusters in the brain is the same as in the megalopa and so is the structure of the neuropile. Thus all neuropiles described above can be found, and even the olfactory-globular tract (OGT) and central body (CB) can be traced (Fig. 6a). Nevertheless there is an increase in the size of the brain. In the zoea-1 the breadth of the brain measured in a transverse section at the level of the central body is $130 \mu \mathrm{m}_{i}$ this increases to $145 \mu \mathrm{m}$ in the zoea-2, $165 \mu \mathrm{m}$ in the zoea-3, $200 \mu \mathrm{m}$ in the zoea-4, and reaches $230 \mu \mathrm{m}$ in the megalopa. Another apparent difference from the megalopa is that in the zoea-1 the optic lobes are situated close to the protocerebral part of the brain and therefore the protocerebral tracts (PCT) are short (Fig. 6b). As the eyes become stalked in successive stages, the optic lobes move away from the brain - the protocerebral tracts (PCT) thereby gradually becoming longer.

The ventral nerve cord of the zoea-1 exhibits almost the same morphology and arrangement of commissures and connectives as the megalopa. Again, an increase in size during development is visible (Fig.6c). The breadth of the subesophageal ganglion (SEG), measured in a cross section near the base of the maxillules, is $120 \mu \mathrm{m}$ in the zoea-1 and increases to $200 \mu \mathrm{m}$ in the megalopa. A striking difference is the absence of the sternal artery in all zoea stages which can be seen first in the zoea-4 as an "Anlage" (Fig. 6d). In the course of premetamorphosis the artery seems to be filled with hemolyph and becomes functional. The first abdominal ganglia (AG) is not yet fused with the thoracic ganglia in the zoea stages but is clearly discernable as a single ganglion (Fig. 6e).

\section{DISCUSSION}

\section{Larval versus adult nervous system}

To a certain degree the larval CNS of Carcinus maenas might be described as a miniaturized version of the adult nervous system. This would imply that adult features, such as the spatial arrangement of ganglia and nerves, as well as the structural organization of the neuropile, were already present in the larvae. Actually, the general shape of the brain is similar in the megalopa and the adult (Tsvileneva \& Titova, 1985).

Fig. 3. Carcinus maenas L. Megalopa; a: whole mount parasagittal section; AG 1-6 $=$ abdominal ganglia 1-6; $\mathrm{B}=$ brain; $\mathrm{CEC}=$ circumesophageal connective; $\mathrm{CG}=$ commissural ganglion; $\mathrm{CS}=$ cardiac stomach; $\mathrm{H}=$ head; $\mathrm{HG}=$ hindgut $\mathrm{HP}=$ hepatopancreas; $\mathrm{MG}=$ midgut $\mathrm{PS}=$ pyloric stomach; SEG = subesophageal ganglion; TG 1-5 = thoracic ganglia 1-5; b: parasagittal section of thoracic ganglia; TG 1-5 = neuropile glomeruli of thoracic ganglia 1-5; SEG $6=$ neuropile of neuromere 6 of the subesophageal ganglion; arrows mark the course of dorsal and ventral connectives; $\mathrm{c}$ : horizontal section of the ventral nerve cord; $\mathrm{CEC}=$ circumesophageal connectives; $\mathrm{CG}=$ commissural ganglion; $\mathrm{E}=$ esophagus; $\mathrm{PEC}=$ postesophageal commissure; $\mathrm{SA}=$ sternal artery; $\mathrm{SEG}=$ subesophageal ganglion the rostro-caudal extension of which is marked by curved arrows; TG $1-5=$ neuropile glomeruli of thoracic ganglia $1-5$; big arrowheads: commissures; small arrowheads: longitudinal tracts; asterisks: medial cell columns; Scale bars: in Fig. $3 a$ 200 $\mu \mathrm{m}$, in Figs 3b, c $50 \mu \mathrm{m}$ 

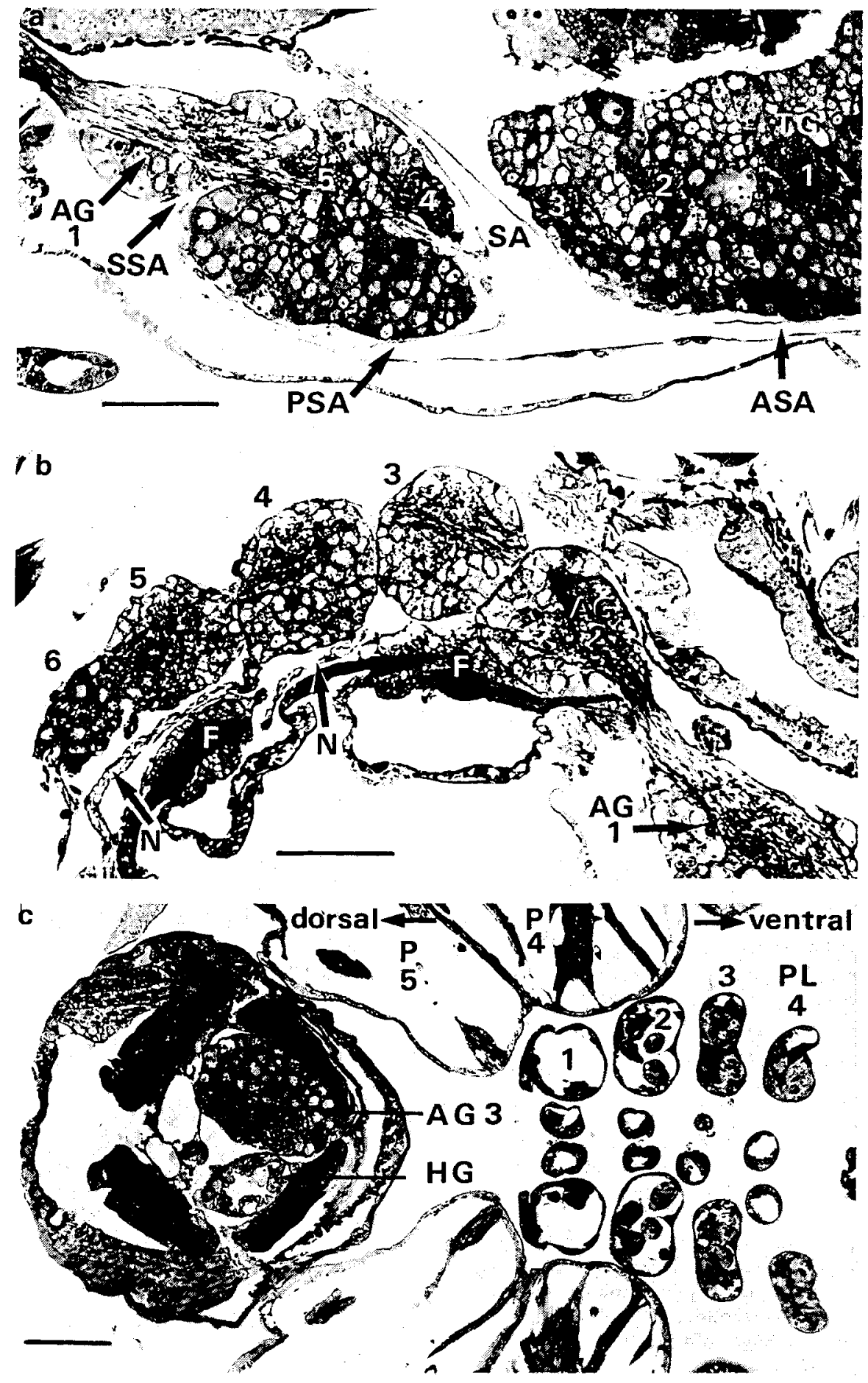
However, there are striking differences in the arrangement of cell somata which in the larva form a coherent cell cortex completely surrounding the neuropile and extending to rounded lobes in some places. In contrast to this, brain cells in the adult are condensed into six well characterized groups with a commonly accepted nomenclature (Bullock \& Horridge, 1965; Tsvileneva \& Titova, 1985; Sandeman et al., 1988). These groups can even be recognized in a comparison between species of different infraorders within the Decapoda. We suggest that splitting of the initially coherent cell cortex into isolated groups is mainly due to an increase in neuropile size and complexity. With the expansion of certain neuropile areas, cells are pushed aside and separated into the groups seen in the adult. It seems likely that at least the complete set of motorneurons is present in the megalopa (Laverack, 1988a). In the case of interneurons there is no evidence as to whether there is an increase in the number of neurons, or just an increase in the complexity of the dendritic branching pattern. In contrast to this, a great number of sensors is added during postmetamorphotic maturation of the animal (Letourneau, 1976). Fibres of these cells project into the central neuropile, multiplying the sensory input. This should result in an ongoing increase in both quantity and qualitative complexity of the neuropile throughout development, followed by extension of neurons and, consequently, separation of the somata into isolated groups.

In adult decapod crustaceans, the neuropile of the olfactory lobes reveal a typical glomerular organization. These glomeruli in which sensory terminals contact interneurons are interpreted as structural correlate for the ability of processing complex sensory stimuli (Sandeman \& Luff, 1973; Derby \& Blaustein, 1988; Sandeman et al., 1990; Johansson, 1991). These neuropile columns are absent in the megalopa which reveal a less prominent, dense and homogeneously structured neuropile of the olfactory lobes. In addition, further structural peculiarities of the adult cerebral neuropile such as hemielipsoid body, glomeruli in the terminal medulla, protocerebral bridge, and clear demarcation between certain neuropiles (Tsvileneva \& Titova, 1985; Blaustein et al., 1988) could not be recognized in the larvae. Thus it seems that increasing complexity of the neuropile characterizes maturation in various cerebral areas.

The fate of single cell clusters in the megalopa is subject to speculation, as it could not be followed in the present study. An exception may be the anterior medial cells (AMC) which are formed by an expansion of the cell cortex. Their location, anteriorly between the protocerebral tracts (PCT), suggests that they are homologous both in the larval and adult brain. In contrast to this, the presence of the paired lobes of the anterior dorsal cells $(\mathrm{ADC})$ is a feature unique to the larva. Probably these cells gradually fuse with the anterior medial cells (AMC) during development and cannot be recognized as separate groups in the adult. In what respect other areas of the larval cell cortex including clusters of the posterior dorsal cells (PDC) and posterior ventral cells (PVC) develop into

Fig. 4. Carcinus maenas L. Megalopa; a: sagittal section of thoracic ganglia; AG $1=$ abdominal ganglion 1; $\mathrm{ASA}=$ anterior branch of the sternal artery; PSA = posterior branch of the sternal artery; $\mathrm{SA}=$ sternal artery; $\mathrm{SSA}=$ side branch of the posterior sternal artery; TG 1-5 = commissures of thoracic ganglia $1-5$; b: parasagittal section of abdominal ganglia; AG 1-6 = abdominal ganglia $1-6 ; F=$ flexor muscles; $N=$ nerves; $c$ : frontal section of the abdomen; $A G 3=$ abdominal ganglion 3 ; HG $=$ hindgut; P 4, $5=$ pereopods 4 and 5; PL 1-4 = pleopods $1-4$; Scale bars: $50 \mu \mathrm{m}$ 


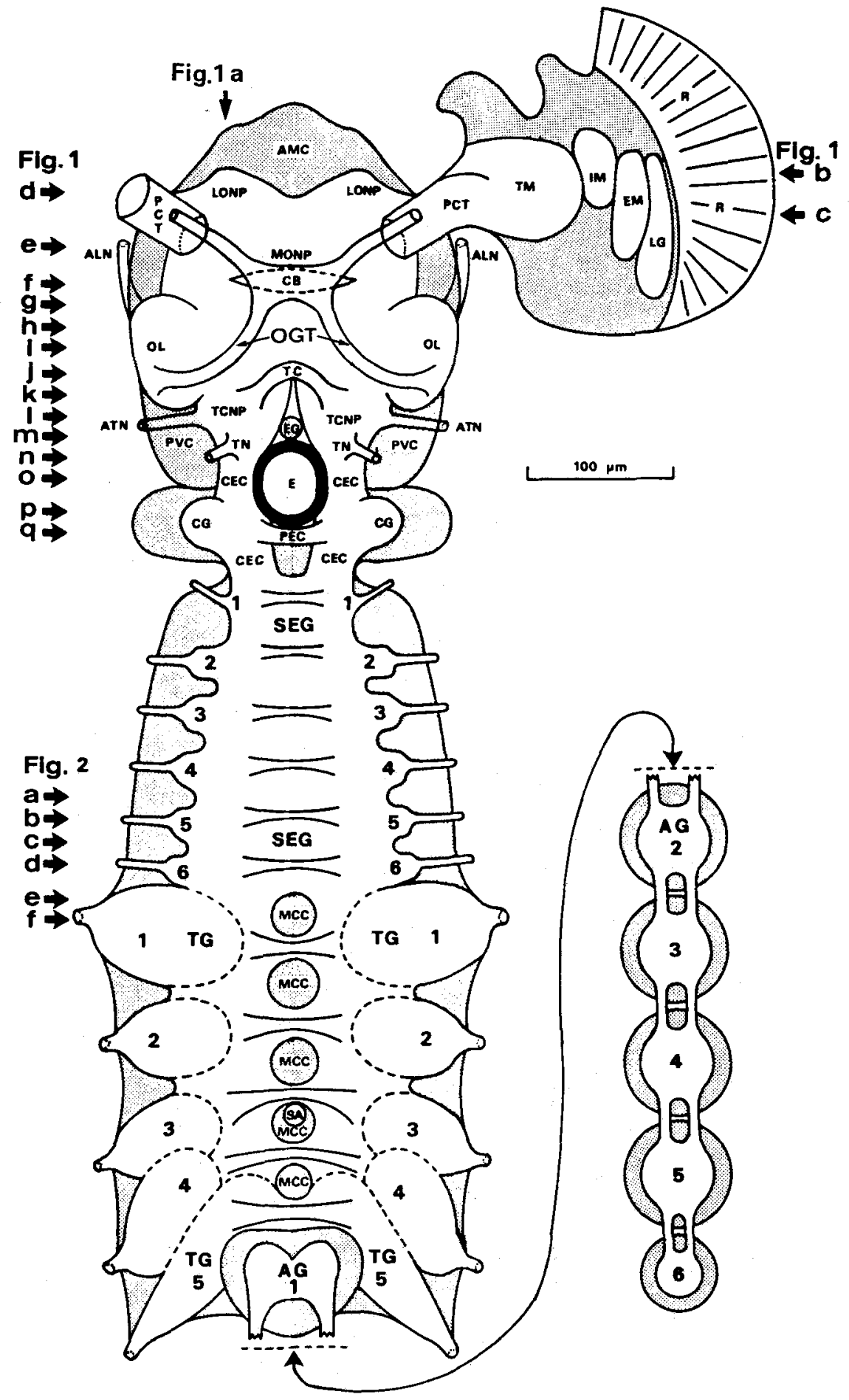


the various adult groups, is a question which remains unanswered and demands further investigation (Bullock \& Horridge, 1965; Tsvileneva \& Titova, 1985).

The ventral nerve cord in larval stages of $C$. maenas is composed of the subesophageal ganglion (SEG) (comprised of six neuromeres), five thoracic ganglia and six abdominal ganglia. In principle, the position of these ganglia as well as the arrangement of commissures and connectives closely correspond to the ladder-like nervous system of the adult (Bullock \& Horridge, 1965). Nevertheless, some significant changes occur during development. The circumesophageal connectives (CEC) are long in the adult, with the commissural ganglia (CG) (part of tritocerebrum) displaced far away from the brain and located beside the esophagus, whereas in the megalopa the commissural ganglia (CG) directly adjoin the other tritocerebral parts. The circumesophageal connectives (CEC) are only recognizable as short, thick fibre bundles, connecting the commissural ganglia (CG) to the subesophageal ganglion (SEG), which is situated closely behind the esophagus. Thus it seems that during development the ventral nerve cord is displaced away from the brain. Furthermore, in the larvae, abdominal ganglia are easily recognized as separate neural centres, whereas in the adult they are relatively small and fused with each other and with the thoracic ganglia (TG). This diminuation and fusion probably reflect the diminished importance of the adult abdomen in terms of locomotion.

In conclusion, postmetamorphotic development of $C$. maenas may be characterized by selective structural reorganization involving various parts of the CNS. We may speculate that these changes should be adaptive to behavioural maturation by rearranging central sensory-motor integration.

\section{The central nervous system during premetamorphosis}

Larval development in Carcinus maenas starts with the hatching of zoea larvae from the egg mass, which is carried by the female. Total in situ development of all successive larval stages lasts between about 40 and 60 days depending on different dynamics of field temperature after hatching (Dawirs, 1985). The transition from the zoea-4 to the megalopa larva is called "premetamorphosis", as the animal undergoes pronounced alterations in morphology and behavioural patterns. While the zoea lives in a planktonic environment, using mandibles, maxillules and maxillae for feeding and maxillipeds I and II for swimming (maxilliped III, pereopods and pleopods only exist as "Anlagen"), the megalopa larva has to cope with life on the benthos. Maxillipeds I to III, together with the other appendages of the head, are now used for feeding, while the unfolded pereopods

Fig. 5. Carcinus maenas L. Schematic model of the larval central nervous system (megalopa). Arrows indicate the positions of successive frontal sections in Figures 1 and 2, including a parasagittal section. AG 1-6 = abdominal ganglia 1-6; ALN = antennulary nerve; AMC = anterior medial cells; $\mathrm{ATN}=$ antennary nerve ${ }_{i} \mathrm{CB}=$ central body $; \mathrm{CEC}=$ circumesophageal connective; $\mathrm{EM}=$ external medulla; $\mathrm{IM}=$ internal medulla; $\mathrm{LG}=$ lamina ganglionaris; LONP $=$ lateral optic neuropile; $\mathrm{MCC}=$ medial cell column; MONP = medial optic neuropile; $\mathrm{PEC}=$ postesophageal commissure; OGT $=$ olfactory globular tract; $\mathrm{OL}=$ olfactory lobe $\mathrm{PCT}=$ protocerebral tract; $\mathrm{PVC}=$ posterior ventral cells; $\mathrm{R}=$ retina; $\mathrm{SA}=$ sternal artery; SEG 1-6 = neuromeres $1-6$ of the subesophageal ganglion with segmental commissures and nerve roots; $\mathrm{TC}=$ tritocerebral commissure $\mathrm{TCNP}=$ tritocerebral neuropile; TG $1-5=$ thoracic ganglia $1-5$ with segmental commissures and nerve roots; $\mathrm{TM}=$ terminal medulla; $\mathrm{TN}=$ tegumentary nerve 

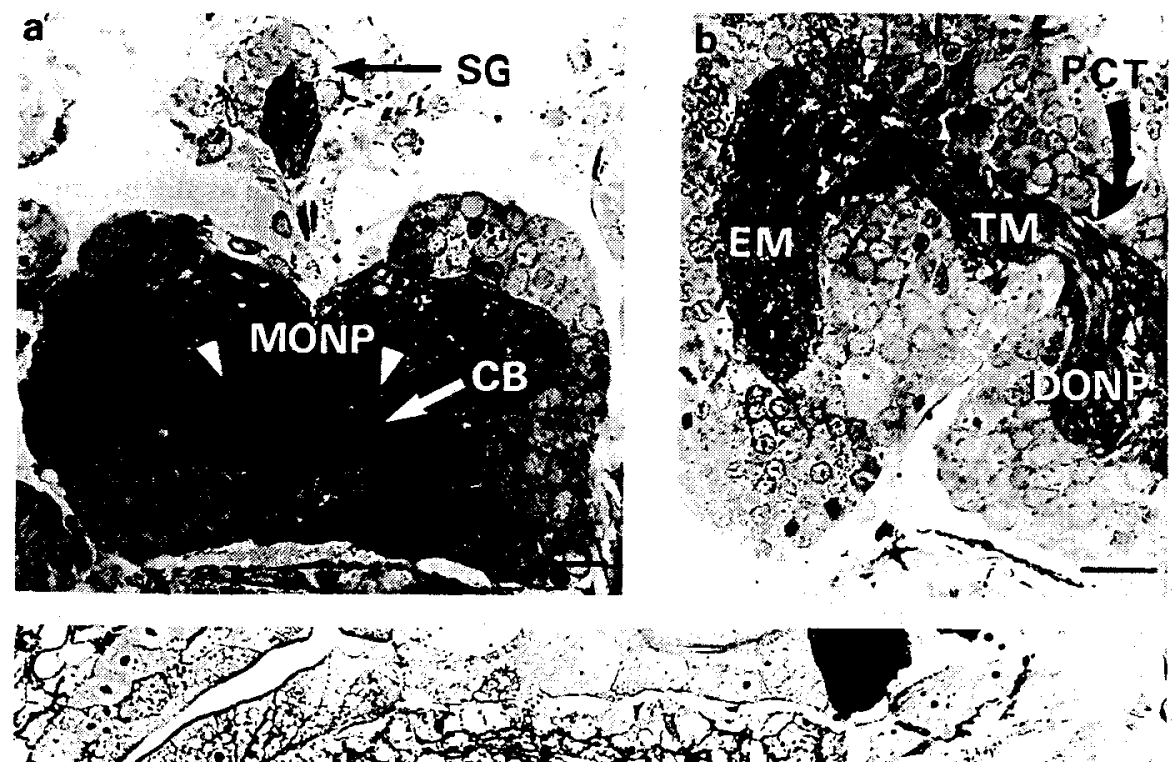

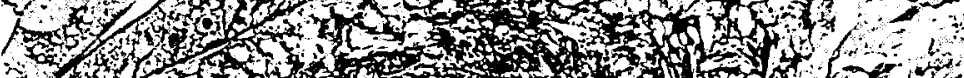
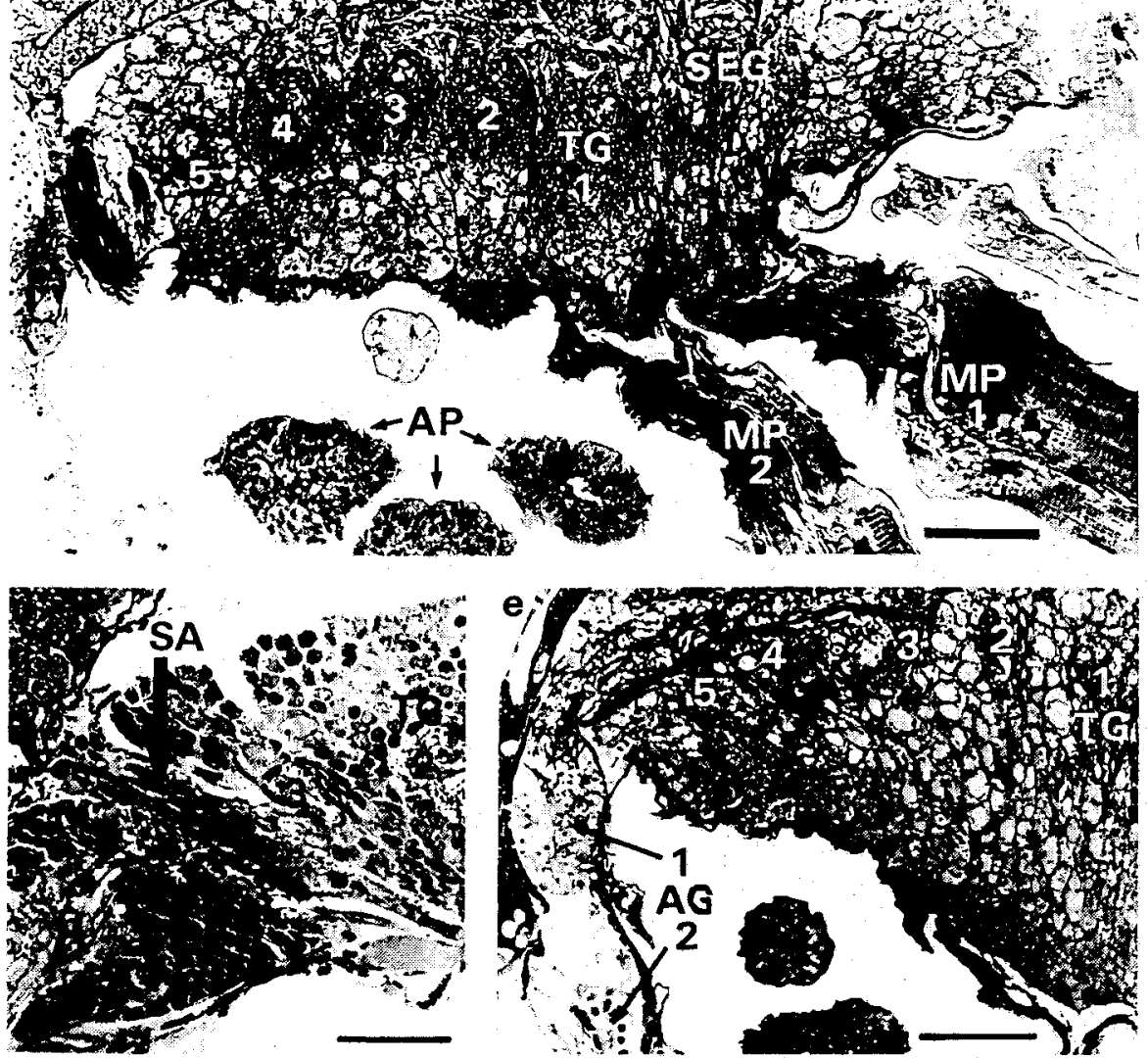
are used for moving on the substrate. The set of abdominal pleopods still enables the larva to swim whenever required.

These fundamental behavioural alterations should demand distinct changes in central nervous integration mainly of the ventral nerve cord, resulting in altered patterns in motor output. It is well documented that central nervous reorganization by synaptic rearrangement is accompanied by both progressive and regressive phenomena (for recent discussion see: Teuchert-Noodt et al., 1991; Dawirs et al., 1992). In this respect, despite the overall structural constancy of the CNS in successive larval stages, the recently documented occurrence of dark staining neurons in the zoea-4 of C. maenas may signify processes of neuronal reorganization (Harzsch \& Dawirs, 1992). Dark neurons which exhibit shrunken outlines and condensed dark nuclei have been the subject of dispute in the past (e.g. Cammermeyer, 1961, 1978; Agardh et al., 1981; Brierley \& Brown, 1981), but are today commonly accepted as an indication of degeneration and degradation (Auer et al., 1985; Gallyas et al., 1990). Since the behavioural repertoire of the larvae should basically depend on the mode of interconnectivity between sensory afferents, interneurons, and motor neurons, we may thus speculate that, with respect to premetamorphosis, important structural adaptation should be expected on the synaptic level.

Acknowledgements. The authors are grateful for technical assistance from B. Höcker, F. Schorn, B. Seeger (larval rearing) and E. Kemming-Graebner, U. Schroeder, and R. Schulze-Gross (histological preparations). We are also indebted to the whole staff of the Marine Station of the "Biologische Anstalt Helgoland" for delivering sampling and rearing facilities. We particularly wish to thank Dr. E. Wahl and M. Janke for providing Artemia spp.-nauplii. Our special thanks are due to Fay Misselbrook for correcting the English draft.

Fig. 6. Carcinus maenas L. a, b: Zoea-1, brain; a: $\mathrm{CB}=$ central body; MONP $=$ medial optic neuropile; $\mathrm{SG}=$ stomatogastric ganglion; arrowheads $=$ olfactory globular tract; $\mathrm{b}: \mathrm{DONP}=$ dorsal optic neuropile; $\mathrm{EM}=$ external medulla; $\mathrm{PCT}=$ protocerebral tract; $\mathrm{TM}=$ terminal medulla; $\mathrm{c}-\mathrm{e}$ : Zoea-4, ventral nerve cord; AG 1,2 = abdominal ganglia 1,2; AP = "Anlagen" of pereopods; MP 1,2 $=$ maxillipeds 1,$2 ; \mathrm{SEG}=$ neuropile of the subesophageal ganglion: TG $1-5=$ neuropile of the thoracic ganglia 1-5; $\mathrm{SA}=$ "Anlage" of the stemal artery; Scale bars: in Figs $6 \mathrm{a}, \mathrm{b} 20 \mu \mathrm{m}$, in Figs $6 \mathrm{c}-\mathrm{e} 40 \mu \mathrm{m}$ 


\section{LITERATURE CITED}

Abbott, N. J., 1971. The organization of the cerebral ganglion in the shore crab, Carcinus maenas. I. Morphology. $-Z$. Zellforsch. mikrosk. Anat. 120,386-400.

Agardh, C. D., Kalimo, H., Olsson, Y. \& Siesjö, B. K., 1981. Reply to the remarks by J. B. Brierley and A. W. Brown. - Acta neuropathol. 55, 323-325.

Auer, R. N., Kalimo, H., Olsson, Y. \& Siesjö, B. K., 1985. The temporal evolution of hypoglycemic brain damage. I: Light- and electron microscopic findings in the rat cerebral cortex. - Acta neuropathol. 67, 13-24.

Bethe, A., 1897. Das Nervensystem von Carcinus maenas. Ein anatomisch-physiologischer Versuch. I. Theil, I. - Mittheilung. - Arch. mikrosk. Anat. EntwMech. 50, 460-546.

Bevengut, M., Simmers, A. J. \& Clarac, F., 1983. Central neuronal projections and neuromuscular organization of the basal region of the shore crab leg. - J. comp. Neurol. 221, 185-198.

Blaustein, D. N., Derby, C. D., Simmons, R. B. \& Beall, A. C., 1988. Structure of the brain and medulla terminalis of the spiny lobster Panulirus argus and the crayfish Procambarus clarkii, with an emphasis on olfactory centers. - J. crust. Biol. 8, 493-519.

Breidbach, O., 1990. Constant topological organization of the coleopteran metamorphosing nervous system: analysis of persistent elements in the nervous system of Tenebrio molitor. - J. Neurobiol. $21,990-1001$.

Brierley, J. B. \& Brown, A. W., 1981. Remarks on the papers by C. D. Agardh et al./H. Kalimo et al. "Hyperglycemic brain injury I, II". - Acta neuropathol. 55; 319-322.

Bullock, T. H. \& Horridge, G. A., 1965. Structure and function in the nervous systems of invertebrates. Freeman, San Francisco, $1719 \mathrm{pp}$.

Cammermeyer, J., 1961. An evaluation of the significance of "dark" neuron. - Ergebn. Anat. EntwGesch. 36, 1-61.

Cammermeyer, J., 1978. Is the solitary dark neuron a manifestation of post mortem trauma to the brain inadequately fixed by perfusion? - Histochemistry $56,97-115$.

Chrachri, A. \& Clarac, F., 1989. Synaptic connections between motor neurons and interneurons in the fourth thoracic ganglion of the crayfish, Procambarus clarkii. - J. Neurophysiol, 62, $1237-1250$.

Cournil, I., Meyrand, P. \& Moulins, M., 1990. Identification of all GABA-immunoreactive neurons projecting to the lobster stomatogastric ganglion. - J. Neurocytol. 19, 478-439.

Dawirs, R. R., 1982. Methodical aspects of rearing decapod larvae, Pagurus bernhardus (Paguridae) and Carcinus maenas (Portunidae). - Helgoländer Meeresunters. 35, 439-464.

Dawirs, R. R., 1985. Temperature and larval development of Carcinus maenas (Decapoda) in the laboratory; predictions of larval dynamics in the sea. - Mar. Ecol. Prog. Ser. 24, $297-302$.

Dawirs, R. R., Teuchert-Noodt, G. \& Kacza, J., 1992. Naturally occurring degrading events in axon terminals of the dentate gyrus and stratum lucidum in the spiny mouse (Acomys cahirhinus) during maturation, adulthood and aging. - Devl. Neurosci. 14, 210-220.

Derby, C. B. \& Blaustein, D. N., 1988. Morphological and physiological characterization of individual olfactory interneurons connecting the brain and eyestalk ganglia of the crayfish. - J. comp. Physiol. (A) 163, 777-794.

Fedesova, T. V., 1978. Neuropile architectonics of the crayfish last abdominal ganglion. - Zool. Jb. (Anat. Ontogenie Tiere) 99, 559-584.

Gallyas, F., Güldner, F. H., Zoltay, G. \& Wolff, J. R., 1990. Golgi-like demonstration of "dark" neurons with an argyrophil III method for experimental neuropathology. - Acta neuropathol. 79, 620-628.

Hanström, B., 1947. The brain, sense organs, and the incretory organs of the head in the Crustacea Malacostraca. - K. fysiogr. Sällsk. Lund Handl. 58, 1-45.

Harris, W. A., 1990. Neurometamorphosis. - J. Neurobiol. 21, 953-957.

Harzsch, S. \& Dawirs, R. R., 1992. Neurometamorphosis in larval stages of Carcinus maenas (Decapoda, Brachyura). In: Rhythmogenesis in neurons and networks. Ed. by N. Elsner \& D. W. Richter. Thieme, Stuttgart, 622 .

Helm, F, 1928. Vergleichend-anatomische Untersuchungen über das Gehirn, insbesondere das "Antennalganglion" der Dekapoden. - Z. Morph. Oekol. Tiere 12, 70-134. 
Holländer, H. \& Vaaland, J. L., 1968. A reliable staining method for semi-thin sections in experimental neuroanatomy. - Brain Res. 10, 120-126.

Johansson, K. U. I., 1991. Identification of different types of serotonin-like immunoreactive olfactory interneurons in four infraorders of decapod crustaceans. - Cell Tissue Res. 264, 357-362.

Krasne, F. B. \& Stirling, C. A., 1972. Synapses of crayfish abdominal ganglia with special attention to afferent and efferent connections of the lateral giant fibers. - Z. Zellforsch. mikrosk. Anat. 127. $526-544$.

Laverack, M. S., 1988a. The numbers of neurons in decapod crustacea. - J. crust. Biol. 8, 1-11.

Laverack, M. S., 1988b. Larval locomotion, sensors, growth and their implication for the nervous system. - Symp. zool. Soc. Lond. 59, 103-122.

Leise, E. M., Hall, W. \& Mulloney, B., 1986. Functional organization of crayfish abdominal ganglia: I. The flexor systems. - J. comp. Neurol. 253, 25-45.

Leise, E. M., Hall, W. M. \& Mulloney, B., 1987. Functional organization of crayfish abdominal ganglia: II. Sensory afferents and extensor motor neurons. - J. comp. Neurol. 266, 495-518.

Letourneau, J. G., 1976. Addition of sensory structures and associated neurons to the crayfish telson during development. - J. comp. Physiol. (A) 110, 13-23.

Levine, R. B. \& Weeks, J. C., 1990. Hormonally mediated changes in simple reflex circuits during metamorphosis in Manduca. - J. Neurobiol. 21, 1022-1036.

Lnenicka, G. A. \& Murphey, R. K., 1989. The refinement of invertebrate synapses during development. - J. Neurobiol. 20, 339-355.

Nässel, D. R. \& Elofsson, R., 1987. Comparative anatomy of the crustacean brain. In: Arthropod brain. Ed. by A. P. Gupta. Wiley, New York, 111-133.

Retzius, G., 1890. Zur Kenntnis des Nervensystems der Crustaceen. - Biol. Unters. 1, 1-50.

Sandeman, D. C. \& Luff, S. E., 1973. The structural organization of glomerular neuropile in the olfactory and accessory lobes of an Australian freshwater crayfish, Cherax destructor. $-\mathrm{Z}$. Zellforsch. mikrosk. Anat. 142, 37-61.

Sandeman, D. C., Sandeman, R. E. \& Aitken, A. R., 1988. Atlas of serotonin-containing neurons in the optic lobes and brain of the crayfish, Cherax destructor. - J. comp. Neurol. 269, 465-478.

Sandeman, R. E., Sandeman, D. C. \& Watson, A. H. D., 1990. Substance P antibody reveals homologous neurons with axon terminals among somata in the crayfish and crab brain. $-\mathrm{J}$. comp. Neurol. $294,569-582$.

Selverston, A. J. \& Moulins, M., 1987. The crustacean stomatogastric system. Springer, Berlin, $345 \mathrm{pp}$.

Silvey, G. E., 1981. The distal limb motor neurons in the thoracic ganglion of the spiny lobster. $-J$. comp. Neurol. 200, 579-595.

Teuchert-Noodt, G., Breuker, K. H. \& Dawirs, R. R., 1991. Neuronal lysosome accumulation in degrading synapses of sensory-motor and limbic subsystems in the duck Anas platyrhynchos: Indication of rearrangements during avian brain development? - Devl. Neurosci. 13, 151-163.

Truman, J. W., 1990. Metamorphosis of the central nervous system of Drosophila. - J. Neurobiol. 21, 1072-1084.

Tsvileneva, V. A., 1978. Nervous structure of the crayfish abdominal ganglia. - Zool. Jb. (Anat. Ontogenie Tiere) 99, 527-558.

Tsvileneva, V. A. \& Titova, V. A., 1985. On the brain structures of decapods. - Zool. Jb. (Anat. Ontogenie Tiere) $113,217-266$.

Turrigiano, G. G. \& Selverston, A. I., 1991. Distribution of Cholecystokinin-like immunoreactivity within the stomatogastric nervous system of four species of decapod crustacea. - J. comp. Neurol. $305,164-176$. 